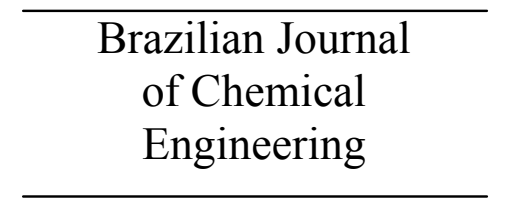

ISSN 0104-6632

Printed in Brazil

www.abeq.org.br/bjche

Vol. 27, No. 02, pp. 299 - 308, April - June, 2010

\title{
REMOVAL OF CADMIUM AND NICKEL FROM AQUEOUS SOLUTION USING EXPANDED PERLITE
}

\author{
M. Torab-Mostaedi ${ }^{*}$, H. Ghassabzadeh ${ }^{2}$, M. Ghannadi-Maragheh ${ }^{1}$, \\ S. J. Ahmadi ${ }^{1}$ and H. Taheri ${ }^{1}$ \\ ${ }^{1}$ Nuclear Fuel Cycle Research School, Nuclear Science and Technology Research Institute, \\ Phone: (+9821) 88221128, Fax: (+9821) 88221116, End of North Karegar Av., P.O. Box: 11365-8486, Tehran, Iran. \\ E-mail: mmostaedi@aeoi.org.ir \\ ${ }^{2}$ Department of Chemical Engineering, Tarbiat Modares University, \\ P.O. Box: 14115-143, Tehran, Iran.
}

(Submitted: July 12, 2009 ; Revised: November 30, 2009 ; Accepted: January 6, 2010)

\begin{abstract}
The adsorption characteristics of cadmium and nickel onto expanded perlite from aqueous solution have been investigated with respect to changes in $\mathrm{pH}$ of solution, adsorbent dosage, contact time and temperature of the solution. The maximum removal efficiency of $\mathrm{Cd}$ (II) is $88.8 \%$ at $\mathrm{pH} 6$ and exposure to 10 $\mathrm{g} / \mathrm{L}$ expanded perlite, while for $\mathrm{Ni}$ (II), it is $93.3 \%$ at the same $\mathrm{pH}$ and exposure to $8 \mathrm{~g} / \mathrm{L}$ adsorbent. For the adsorption of both metals, the Freundlich isotherm model fitted the equilibrium data better than the Langmuir isotherm model. Experimental data are also evaluated in terms of kinetic characteristics of adsorption and it was found that the adsorption process for both metal ions follows well pseudo-second-order kinetics. Thermodynamic functions, the change of free energy $\left(\Delta \mathrm{G}^{\circ}\right)$, enthalpy $\left(\Delta \mathrm{H}^{\circ}\right)$ and entropy $\left(\Delta \mathrm{S}^{\circ}\right)$ of adsorption are also calculated for each metal ion. The results show that the adsorption of these metal ions on expanded perlite is feasible and exothermic at $20-50^{\circ} \mathrm{C}$.

Keywords: Expanded Perlite; Cadmium; Nickel; Adsorption; Kinetics.
\end{abstract}

\section{INTRODUCTION}

The progressive increase of industrial technology results in a continuous increase of pollution, so that a great effort has been devoted to minimizing these hazardous pollutants and, therefore, avoiding their dangerous effects on animals, plants and humans. Metals can pose health hazards if their concentrations exceed allowable limits. Even when the concentrations of metals do not exceed these limits, there is still a potential for long-term contamination, since heavy metals are known to be accumulative within biological systems (Ong et al., 2007; Morais Barros et al., 2006, Silva et al., 2003). Cadmium, zinc, copper, nickel, mercury, and chromium are often detected in industrial wastewaters, which are originated from metal plating, mining activities, smelting, battery manufacture, pesticides, nuclear industry, etc. Several methods have been applied over the years in order to eliminate these metal ions from industrial waste waters and soils. The common traditional methods used for removal of heavy metal ions from aqueous solutions include ionexchange, solvent extraction, chemical precipitation, phytoextraction, ultra-filtration, reverse osmosis, electrodialysis and adsorption.

Adsorption using low-cost adsorbents has been effectively applied to remove heavy metals from aqueous solutions (Unlü and Ersoz., 2006). Cadmium and nickel are of major concern because of their frequent handling in developing countries and their non-degradable nature. Cadmium is one of the heavy metals with the greatest potential hazard to

*To whom correspondence should be addressed 
humans and the environment. Chronic exposure to elevated level of cadmium is known to cause renal dysfunction, bone degeneration, liver damage, and blood damage. The chronic toxicity of nickel to humans and the environment is also well-known and high nickel concentrations cause gastrointestinal irritation and lung and bone cancers. In recent years, various adsorbents have been used for removal of $\mathrm{Cd}$ (II) and $\mathrm{Ni}$ (II) from aqueous solution (Benguella and Benaissa, 2002; Gomez-Salazar et al., 2003; Gupta et al., 2003; Singh et al., 2005; Nwabanne and Ibbokwe, 2008). However, new adsorbents with local availability, high adsorption capacity and composed of economical materials are still needed.

Perlite is a naturally occurring dense, glassy volcanic rhyolitic rock and can be expanded up to 20 times its original volume when heated rapidly at 800 $1200^{\circ} \mathrm{C}$ (Alkan and Dogan, 2002). Expanded perlite (EP) acts as an excellent insulator, both thermal and acoustical, resists fire and is classified as an ultralight weight material. The expanded perlite is white in color, and has a density of about $32 \mathrm{~g} / \mathrm{L}$. Perlite is generally chemically inert and has a $\mathrm{pH}$ of approximately 7. Perlite is very cheap and easily available in Iran markets. The cost of expanded perlite is less than US\$ 0.2 per $\mathrm{kg}$ in Iran. This could make it a viable candidate as an economical adsorbent for removing heavy metals such as lead, copper, cadmium and chromium (Alkan and Dogan, 2001; Chakir et al., 2002; Sar1 et al., 2007a).

The objective of the present study is to investigate the adsorption potential of Iranian expanded perlite (EP) in the removal of $\mathrm{Cd}$ (II) and $\mathrm{Ni}$ (II) ions from aqueous solution. The effects of $\mathrm{pH}$, adsorbent dosage, contact time and temperature on adsorption capacity of EP have been investigated. The Langmuir and Freundlich isotherms models are used to investigate equilibrium data. The adsorption mechanisms of $\mathrm{Cd}$ (II) and $\mathrm{Ni}$ (II) ions onto $\mathrm{EP}$ are also evaluated in terms of kinetics and thermodynamics.

\section{EXPERIMENTAL}

Expanded perlite samples were obtained from Kaneh Azar Co. (Tabriz, Iran). The expanded perlite was used without any chemical treatment for the sorption reported here. The chemical composition of the perlite determined by XRF is given in Table 1 . The specific surface area of expanded perlite is $1.89 \mathrm{~m}^{2} / \mathrm{g}$. It was measured by BET $\mathrm{N}_{2}$ adsorption. The particle size ranged between 10 and $40 \mu \mathrm{m}$ and its porosity was $82 \%$. Cadmium and nickel solutions and standards were prepared by using analytical grade cadmium chloride $\left(\mathrm{CdCl}_{2}\right)$ and nickel chloride $\left(\mathrm{NiCl}_{2} \cdot 6 \mathrm{H}_{2} \mathrm{O}\right)$. The solutions of $\mathrm{Cd}$ (II) and $\mathrm{Ni}$ (II) were prepared from stock solutions containing 1000 $\mathrm{mgL}^{-1}$ of $\mathrm{Cd}$ (II) and $\mathrm{Ni}$ (II), respectively. All the solutions in the study were prepared using double distilled water.

\section{Table 1: Chemical composition of expanded perlite}

\begin{tabular}{|c|c|}
\hline Constituent & Percentage (wt. \%) \\
\hline $\mathrm{SiO}_{2}$ & 79.6 \\
$\mathrm{Al}_{2} \mathrm{O}_{3}$ & 11.5 \\
$\mathrm{~K}_{2} \mathrm{O}$ & 4.8 \\
$\mathrm{CaO}$ & 0.8 \\
$\mathrm{Fe}_{2} \mathrm{O}_{3}$ & 0.8 \\
$\mathrm{Na}_{2} \mathrm{O}$ & 0.5 \\
$\mathrm{MgO}$ & 0.5 \\
$\mathrm{SO}_{3}$ & 0.2 \\
$\mathrm{TiO}_{2}$ & 0.1 \\
$\mathrm{MnO}_{2}$ & 0.065 \\
Loss on ignition & 1.135 \\
\hline
\end{tabular}

Adsorption experiments were carried out at the desired $\mathrm{pH}$ value, contact time and adsorbent dosage level using the necessary adsorbent in $250 \mathrm{~mL}$ conical flasks containing $100 \mathrm{~mL}$ of the metal ion solutions. The flasks were sealed with Parafilm "M". The initial concentrations of both metals were 5,10 , $20,30,40$, and $50 \mathrm{mgL}^{-1}$. Samples were collected at $5,10,20,30,45,60,90,120,150$, and $180 \mathrm{~min}$ to determine optimal shaking time. The $\mathrm{pH}$ values were adjusted to $3,4,5,5.5,6,6.5,7$, and 8 using $0.1 \mathrm{M}$ $\mathrm{NaOH}$ or $\mathrm{HNO}_{3}$ solution. The effect of adsorbent dosage on $\mathrm{Cd}$ (II) and $\mathrm{Ni}$ (II) removal was studied by using $10 \mathrm{mgL}^{-1}$ initial $\mathrm{Cd}$ (II) and $\mathrm{Ni}$ (II) concentrations in conjunction with $1,2,4,6,8,10$, 12 , and $15 \mathrm{gL}^{-1}$ of expanded perlite. The adsorption studies were also carried out at $20,30,40$, and $50^{\circ} \mathrm{C}$ to determine the effect of temperature and to evaluate the adsorption thermodynamic parameters. During the adsorption process, the flasks were agitated on a shaker at 170rpm. The contents of the flasks were filtrated through filter paper and the filtrate was analyzed for metal concentration by using inductively coupled plasma-atomic emission spectroscopy (ICP-AES). The amount of Cd (II) and Ni (II) absorbed per unit mass of adsorbent $\left(\mathrm{q}_{\mathrm{e}}\right)$ was calculated from the following equation.

$\mathrm{q}_{\mathrm{e}}=\frac{\mathrm{V}\left(\mathrm{C}_{\mathrm{i}}-\mathrm{C}_{\mathrm{e}}\right)}{\mathrm{M}}$

where $C_{i}$ and $C_{e}$ represent initial and equilibrium concentrations of metal ions in aqueous phase, respectively. $\mathrm{V}$ is the volume of the solution in liters 
(L) and $\mathrm{M}$ is the mass of the adsorbent in grams. The adsorption percentage of metal ions was calculated as follows:

$$
\text { Adsorption }(\%)=\frac{C_{i}-C_{f}}{C_{i}} \times 100
$$

where $\mathrm{C}_{\mathrm{i}}$ and $\mathrm{C}_{\mathrm{f}}$ are the initial and final metal ion concentrations, respectively.

The average absolute value of relative error, AARE, is used to compare the predicted results with the experimental data. This is defined as follows:

$$
\begin{aligned}
& \text { AARE }=\frac{1}{\text { NDP }} \\
& \sum_{i=1}^{\text {NDP }} \frac{\mid \text { Predicted value-Experimental value } \mid}{\text { Experimental value }}
\end{aligned}
$$

in which NDP is the number of data points.

\section{RESULTS AND DISCUSSION}

\section{Effect of Adsorbent Dosage}

Adsorbent dosage is one of the important parameters in adsorption processes because it determines the capacity of an adsorbent for a given initial concentration of the adsorbate under a given set of operating conditions. Figure 1 shows the effect of adsorbent dosage on the adsorption of Cd (II) and $\mathrm{Ni}$ (II) ions. As can be seen in this figure, the adsorption percentage increases with increasing adsorbent dosage from 33 to $87 \%$ for Cd (II) and from 43 to $90.5 \%$ for Ni (II) ions. The increase in the removal efficiency may be attributed to the fact that, with an increase in the adsorbent dosage, more adsorbent surface is available for the solute to be adsorbed (Gence et al., 2003). This figure shows that the adsorption percentage becomes almost constant at $10 \mathrm{~g} / \mathrm{L}$ for $\mathrm{Cd}$ (II) and at $8 \mathrm{~g} / \mathrm{L}$ for Ni (II). On this basis, these values are used for further experiments.

\section{Effect of pH}

The $\mathrm{pH}$ of the adsorbate solutions has been identified as the most important parameter governing sorption of metal ions on different adsorbents. This is partly due to the fact that hydrogen ions themselves are a strong competing sorbate and partly to the fact that the solution $\mathrm{pH}$ influences the chemical speciation of metal ions. The effect of $\mathrm{pH}$ on adsorption of cadmium and nickel ions onto EP is shown in Figure 2. As shown in this figure, at low $\mathrm{pH}$ values, the adsorption percentage is low due to the increase in positive charge density(protons) on the surface sites, resulting in electrostatic repulsion between the metal ions $\left(\mathrm{Cd}^{2+}\right.$ or $\left.\mathrm{Ni}^{2+}\right)$ and edge groups with positive charge $\left(\mathrm{Si}-\mathrm{OH}^{2+}\right)$ on the surface. Electrostatic repulsion decreases with increasing $\mathrm{pH}$ because of the reduction of positive charge density on the sorption edges, thus resulting in an increase in metal ion adsorption on the surface. In an alkaline medium, the surface of EP becomes negatively charged. According to Figure 2, the maximum adsorption of both metal ions occurred at $\mathrm{pH}$ 6.0. At $\mathrm{pH}$ values higher than 6, metal precipitation occurred and adsorbent capacity was decreased with accumulation of metal ions. Therefore, an optimum $\mathrm{pH} 6.0$ was selected for further experiments.

\section{Effect of Shaking Time}

The effect of shaking time on adsorption of $\mathrm{Cd}$ (II) and Ni (II) on EP is illustrated in Figure 3. This figure indicates that the metal concentration in aqueous solution decreases rapidly during first 30 min and remains nearly constant after 120 min for $\mathrm{Cd}$ (II) and $105 \mathrm{~min}$ for $\mathrm{Ni}$ (II), suggesting that the adsorption of both metal ions is fast. Therefore, 120 min and $105 \mathrm{~min}$ are selected as optimum shaking times for $\mathrm{Cd}$ (II) and $\mathrm{Ni}$ (II), respectively.

\section{Adsorption Isotherm Models}

The equilibrium adsorption isotherm is of fundamental importance in the design of adsorption systems. The Langmuir model, which is valid for monolayer adsorption onto a surface containing a finite number of identical sites, is the model most frequently used to represent data on adsorption from solution. The exact shape of the adsorption isotherm for a heterogeneous adsorbent will depend on the distribution of the $\mathrm{K}_{\mathrm{L}}$ values or, more specifically, on the frequency distribution of the adsorption energies of site on the adsorbent (Langmuir, 1918; Do, 1998). This model can be expressed as:

$$
\begin{aligned}
& \mathrm{q}_{\mathrm{e}}=\frac{\mathrm{q}_{\mathrm{m}} \mathrm{K}_{\mathrm{L}} \mathrm{C}_{\mathrm{e}}}{1+\mathrm{K}_{\mathrm{L}} \mathrm{C}_{\mathrm{e}}} \\
& \text { or } \frac{\mathrm{C}_{\mathrm{e}}}{\mathrm{q}_{\mathrm{e}}}=\frac{1}{\mathrm{q}_{\mathrm{m}} \mathrm{K}_{\mathrm{L}}}+\frac{\mathrm{C}_{\mathrm{e}}}{\mathrm{q}_{\mathrm{m}}}
\end{aligned}
$$


where $\mathrm{q}_{\mathrm{e}}$ is the equilibrium metal ion concentration on the adsorbent $(\mathrm{mg} / \mathrm{g}), \mathrm{C}_{\mathrm{e}}$ the equilibrium metal ion concentration in the solution $(\mathrm{mg} / \mathrm{L}), \mathrm{q}_{\mathrm{m}}$ the monolayer adsorption capacity of the adsorbent $(\mathrm{mg} / \mathrm{g})$ and $\mathrm{K}_{\mathrm{L}}$ represents the Langmuir adsorption constant (L/mg), related to the free energy of adsorption. This type of adsorption is valid when: (i) the adsorbent surface is homogeneous; (ii) both surface and bulk phases exhibit ideal behavior; and (iii) the adsorption film is monomolecular.

The Freundlich model (Weber, 1972; Do, 1998) is an empirical equation and can be applied for non-ideal sorption on heterogeneous surfaces and multilayer sorption. The equation is commonly given by:

$\mathrm{q}_{\mathrm{e}}=\mathrm{K}_{\mathrm{F}} \mathrm{C}_{\mathrm{e}}^{1 / \mathrm{n}}$ where $\mathrm{K}_{\mathrm{F}}$ is a constant related to the adsorption capacity and $1 / \mathrm{n}$ is a empirical parameter related to the adsorption intensity, which varies with the heterogeneity of the material.

The non-linearized form of the Langmuir isotherm is used to obtain the constants of this model. The Langmuir model constants are given in Table 2. The correlation coefficient $\left(\mathrm{R}^{2}\right)$ is found to be 0.93 for the adsorption of $\mathrm{Cd}$ (II) ion and 0.953 for the adsorption of $\mathrm{Ni}$ (II) ion indicating that the Langmuir model is able to describe adsorption of both metal ions adequately. The value of the maximum capacity $\left(\mathrm{q}_{\mathrm{m}}\right)$ is found to be $1.79(\mathrm{mg} / \mathrm{g})$ for $\mathrm{Cd}$ (II) ions and $2.24(\mathrm{mg} / \mathrm{g})$ for $\mathrm{Ni}$ (II) ions. The $\mathrm{K}_{\mathrm{L}}$ value is $0.919(\mathrm{~L} / \mathrm{mg})$ for $\mathrm{Cd}$ (II) ion and 1.922 ( $\mathrm{L} / \mathrm{mg}$ ) for $\mathrm{Ni}$ (II) ion.

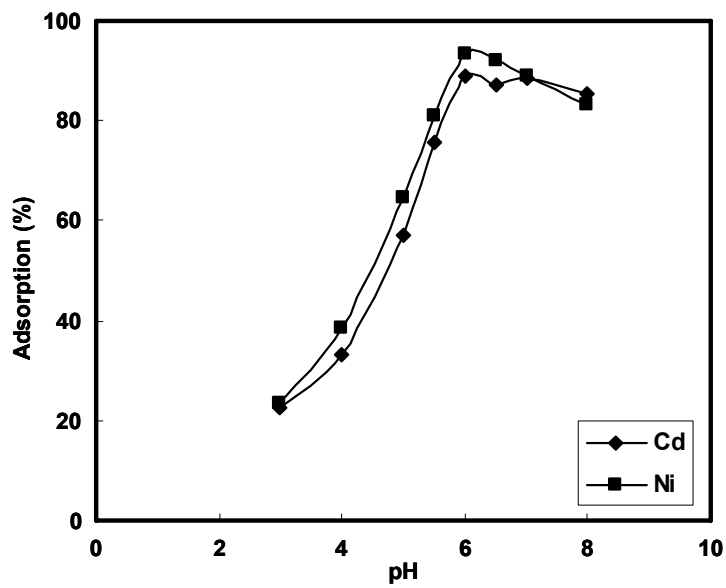

Figure 2: Effect of $\mathrm{pH}$ on the adsorption of $\mathrm{Cd}$ (II) and $\mathrm{Ni}$ (II) on EP (metal concentration: 10 $\mathrm{mg} / \mathrm{L}$ )

Figure 1: Effect of adsorbent dosage on the adsorption of $\mathrm{Cd}$ (II) and $\mathrm{Ni}$ (II) onto $\mathrm{EP}$ (metal concentration: $10 \mathrm{mg} / \mathrm{L}$; temperature: $20^{\circ} \mathrm{C}$ )

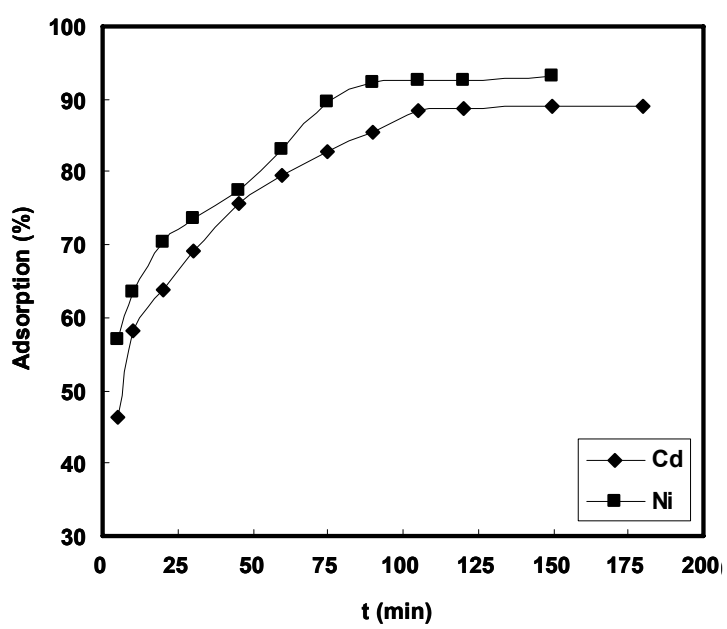

Figure 3: Effect of contact time on the adsorption of $\mathrm{Cd}$ (II) and $\mathrm{Ni}$ (II) on EP (metal concentration: $10 \mathrm{mg} / \mathrm{L}$; temperature: $20^{\circ} \mathrm{C}$ ) 
Table 2: Langmuir and Freundlich constants for adsorption of Cd (II) and Ni (II) on EP

\begin{tabular}{|c|c|c|c|c|c|c|c|}
\hline & \multicolumn{4}{|c|}{ Langmuir model } & \multicolumn{3}{c|}{ Freundlich model } \\
\hline Metal ions & $\left.\mathbf{q}_{\mathbf{m}} \mathbf{( m g} / \mathbf{g}\right)$ & $\mathbf{K}_{\mathbf{L}} \mathbf{( L / m g )}$ & $\mathbf{R}$ & $\mathbf{A A R D} \%$ & $\mathbf{1 / n}$ & $\mathbf{K}_{\mathbf{F}}$ & AARD\% \\
\hline $\mathrm{Cd}$ (II) & 1.791 & 0.919 & $0.0352-0.851$ & 14.59 & 0.263 & 0.79 & 4.88 \\
\hline $\mathrm{Ni}$ (II) & 2.24 & 1.922 & $0.0169-0.866$ & 14.72 & 0.20 & 1.22 & 6.42 \\
\hline
\end{tabular}

The shape of the isotherm can also be considered when predicting whether an adsorption system is "favorable" or "unfavorable". The essential characteristic of a Langmuir isotherm can be expressed in terms of a dimensionless separation factor or equilibrium parameter R (Alkan and Dogan, 2001), which is defined by the following equation:

$$
\mathrm{R}=\frac{1}{1+\mathrm{K}_{\mathrm{L}} \mathrm{C}_{\mathrm{e}}}
$$

According to the value of $\mathrm{R}$, the isotherm shape may be interpreted as given in Table 3 . As shown in Table 2, the adsorption of Cd (II) ion and Ni (II) ion onto perlite is favorable. A plot of $\ln \mathrm{q}_{\mathrm{e}}$ vs $\ln \mathrm{C}_{\mathrm{e}}$ enables the empirical constants $K_{F}$ and $1 / n$ to be determined from the intercept and slope of the linear regression. Fig. 5 shows the Freundlich isotherm obtained by plotting $\ln \mathrm{q}_{\mathrm{e}}$ versus $\ln \mathrm{C}_{\mathrm{e}}$ values. Table 2 also presents the results for the Freundlich isotherm model constants and correlation coefficient. The values of $K_{f}$ and $1 / \mathrm{n}$ are found to be 0.79 and 0.263 for $\mathrm{Cd}$ (II) ion and 1.22 and 0.20 for $\mathrm{Ni}$ (II) ion. The $1 / \mathrm{n}$ values are between 0 and 1 , indicating that the adsorption of both metal ions onto EP is favorable under the selected operating conditions.

The $\mathrm{R}^{2}$ values are found to be 0.985 and 0.980 for $\mathrm{Cd}$ (II) ion and $\mathrm{Ni}$ (II) ion, respectively. The comparison of experimental data with the values of $\mathrm{q}_{\mathrm{e}}$ obtained by both models is shown in Figs. 4 and 5 . As can be seen in these figures, the adsorption results obtained are best described by the Freundlich isotherm model.

Table 3: Separation factor for shape of isotherm

\begin{tabular}{|l|c|}
\hline Value R & Type of adsorption \\
\hline $\mathrm{R}>1.0$ & Unfavorable \\
$\mathrm{R}=1.0$ & Linear \\
$0<\mathrm{R}<1.0$ & Favorable \\
$\mathrm{R}=0$ & Irreversible \\
\hline
\end{tabular}

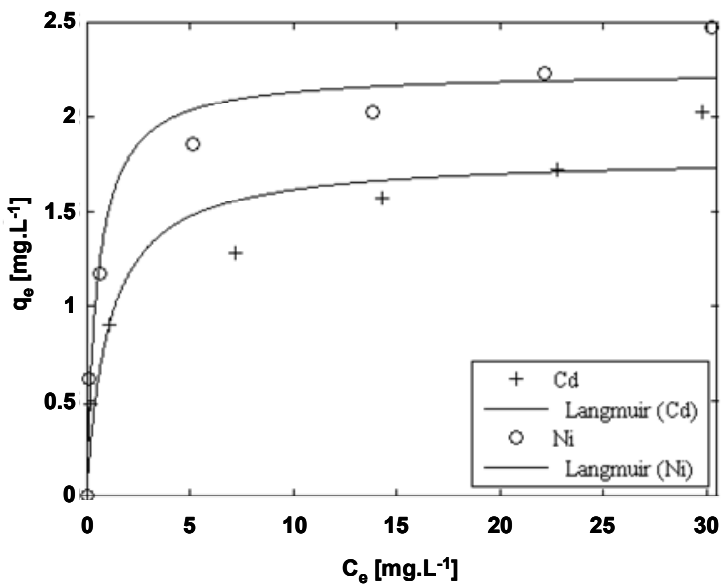

Figure 4: Comparison of the experimental data with the $\mathrm{q}_{\mathrm{e}}$ values obtained by Langmuir isotherms

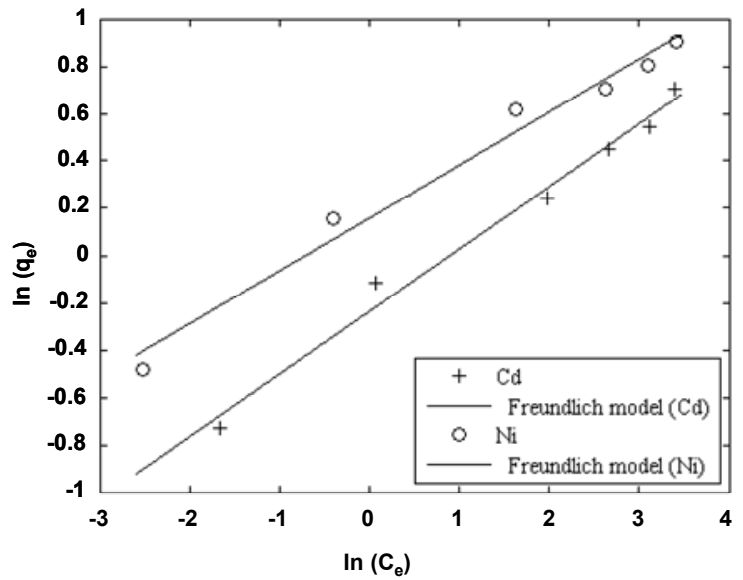

Figure 5: Comparison of the experimental data with the $\mathrm{q}_{\mathrm{e}}$ values obtained by Freundlich isotherms 


\section{Adsorption Kinetics}

In order to clarify the adsorption kinetics of $\mathrm{Cd}$ (II) and Ni (II) ions onto EP Lagergren pseudo-firstorder and pseudo-second-order kinetic models are applied to the experimental data. The Lagergren pseudo-first-order rate equation (Lagergren, 1989) used by researchers to study the kinetics of heavy metals adsorption is as follows:

$\ln \left(\mathrm{q}_{\mathrm{e}}-\mathrm{q}_{\mathrm{t}}\right)=\ln \mathrm{q}_{\mathrm{t}}-\mathrm{k}_{1} \mathrm{t}$

where $\mathrm{q}_{\mathrm{t}}(\mathrm{mg} / \mathrm{g})$ is the amount of the metal ion adsorbed at $\mathrm{t}(\mathrm{min})$ and $\mathrm{k}_{1}$ is the rate constant of the adsorption $\left(\mathrm{min}^{-1}\right)$. Fig. 6 shows the Lagergren pseudo-first-order model for the kinetics of cadmium and nickel adsorption on EP.

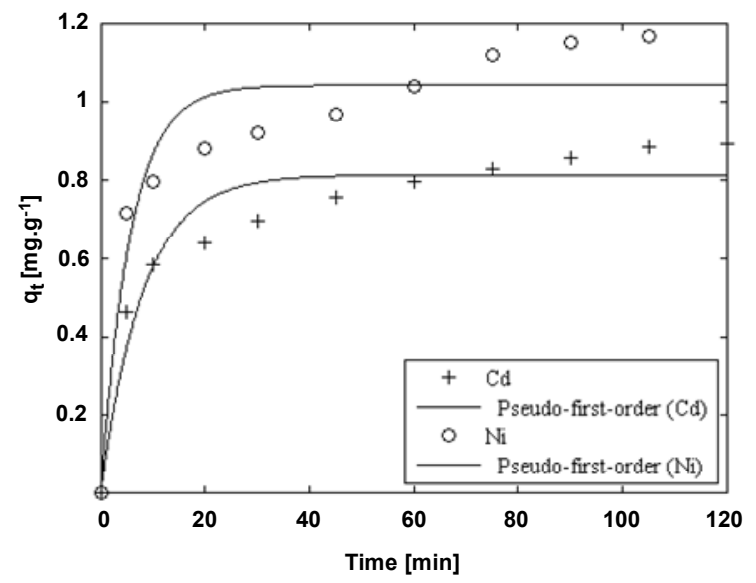

Figure 6: The Lagergren pseudo-first-order model plot for cadmium and nickel adsorption on expanded perlite

Ho and McKay (1999) used a pseudo-secondorder reaction rate equation to study the kinetics of adsorption of heavy metals on peat. The pseudosecond-order equation is given by:

$$
\frac{\mathrm{t}}{\mathrm{q}_{\mathrm{t}}}=\frac{1}{\mathrm{k}_{2} \mathrm{q}_{\mathrm{t}}^{2}}+\left(\frac{1}{\mathrm{q}_{\mathrm{e}}}\right) \mathrm{t}
$$

where $\mathrm{k}_{2}(\mathrm{~g} / \mathrm{mg} \mathrm{min})$ is the rate constant of the pseudo-second-order equation. This model is more likely to predict the kinetic behavior of adsorption with chemical sorption being the rate controlling step (Wen et al., 2006).

The rate constant $\left(\mathrm{k}_{2}\right)$ and correlation coefficient of this equation are listed in Table 4. It is clear from the results that the adsorption of $\mathrm{Cd}$ (II) and $\mathrm{Ni}$ (II) ions onto EP follows well the pseudo-second-order kinetics. Fig. 7 shows Ho's pseudo-second-order model for the kinetics of cadmium and nickel adsorption on EP.

The first-order kinetic rate constants reported by a few other researchers are $1.398 \mathrm{~h}^{-1}$ for cadmium on fly ash (Mathialagan and Viraraghavan, 2002), and $0.44 \mathrm{~h}^{-1}$ for cadmium adsorption on Aspergillus niger biomass (Kapoor, 1998). A comparison of the firstorder rate constants from the present study with other studies shows that the rate of cadmium and nickel adsorption on expanded perlite is quite rapid (Srivastava et al., 2009).

\section{Adsorption Thermodynamics}

The temperature range used in the study was from 20 to $50^{\circ} \mathrm{C}$. Thermodynamic parameters, including the change in the free energy $\left(\Delta \mathrm{G}^{\circ}\right)$, enthalpy $\left(\Delta \mathrm{H}^{\circ}\right)$ and entropy $\left(\Delta \mathrm{S}^{\circ}\right)$, were determined using the following equation:

$$
\begin{aligned}
& \Delta \mathrm{G}^{\circ}=-\mathrm{RT} \ln \mathrm{K}_{\mathrm{D}} \\
& \Delta \mathrm{G}^{\circ}=\Delta \mathrm{H}^{\circ}-\mathrm{T} \Delta \mathrm{S}^{\circ}
\end{aligned}
$$

where $\mathrm{R}$ is the universal gas constant (8.314 $\mathrm{J} / \mathrm{mol} . \mathrm{K}), \mathrm{T}$ is the temperature $(\mathrm{K})$ and $\mathrm{K}_{\mathrm{D}}$ is the equilibrium constant. The enthalpy change $\left(\Delta \mathrm{H}^{\circ}\right)$ and entropy change $\left(\Delta \mathrm{S}^{\circ}\right)$ of adsorption are obtained from the following equation

$\ln \mathrm{K}_{\mathrm{D}}=\frac{\Delta \mathrm{S}^{\circ}}{\mathrm{R}}-\frac{\Delta \mathrm{H}^{\circ}}{\mathrm{RT}}$

According to Equation (10), $\left(\Delta \mathrm{H}^{\circ}\right)$ and $\left(\Delta \mathrm{S}^{\circ}\right)$ parameters can be calculated from the slope and intercept of a plot of $\operatorname{lnK}_{\mathrm{D}}$ versus $1 / \mathrm{T}$, respectively (Fig. 8).

Table 4: Lagergren rate equation constants and pseudo-second-order rate equation constants for adsorption of Cd (II) and Ni (II) onto EP

\begin{tabular}{|c|c|c|c|c|c|c|}
\hline & \multicolumn{3}{|c|}{ Lagergren rate equation } & \multicolumn{3}{c|}{ pseudo-second-order rate equation } \\
\hline Metal ions & $\mathbf{k}_{\mathbf{1}}\left(\mathbf{m i n}^{-1}\right)$ & $\mathbf{R}^{\mathbf{2}}$ & $\mathbf{A A R D} \%$ & $\mathbf{k}_{\mathbf{2}} \mathbf{( g / \mathbf { m g } \mathbf { m i n } )}$ & $\mathbf{R}^{\mathbf{2}}$ & $\mathbf{A A R D} \%$ \\
\hline $\mathrm{Cd}$ (II) & 0.124 & 0.933 & 8.44 & 0.213 & 0.994 & 6.05 \\
$\mathrm{Ni}$ (II) & 0.177 & 0.92 & 9.49 & 0.193 & 0.991 & 7.60 \\
\hline
\end{tabular}




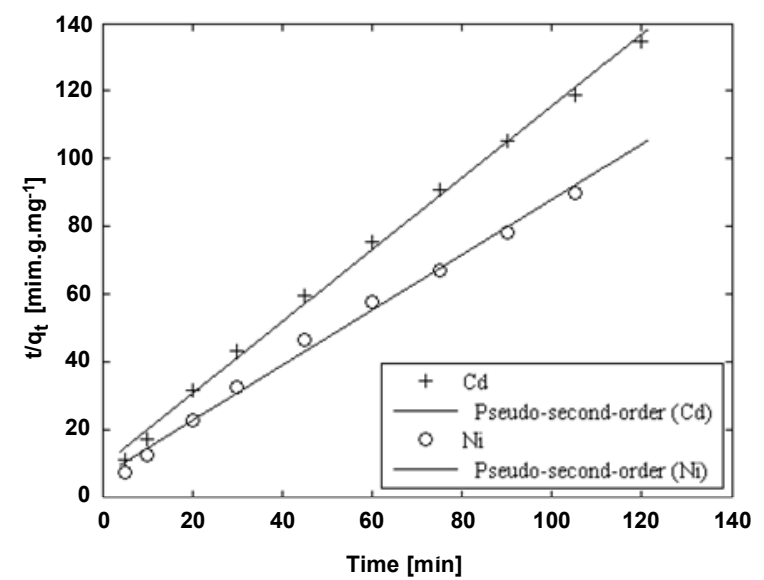

Figure 7: Ho's pseudo-second-order model plot for cadmium and nickel adsorption on expanded perlite

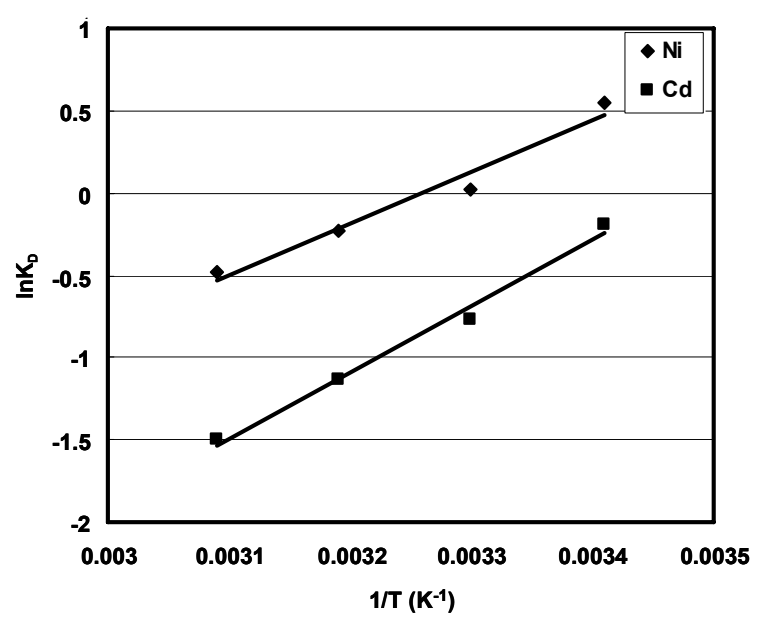

Figure 8: Plot of $\ln K_{D}$ vs. 1/T for estimation of thermodynamic parameters for the adsorption of Cd (II) and Ni (II) on EP (metal concentration: $10 \mathrm{mg} / \mathrm{L}$ ).

From Equation (8), the Gibbs free energy change of adsorption $\left(\Delta \mathrm{G}^{\circ}\right)$ is calculated by using $\ln \mathrm{K}_{\mathrm{D}}$ values for different temperatures. The values of $\Delta \mathrm{G}^{\circ}$ are found to be $0.462,1.944,2.94$ and $4.03 \mathrm{~kJ} / \mathrm{mol}$ for the adsorption of $\mathrm{Cd}$ (II) and $-1.34,-0.3,0.62$ and $1.29 \mathrm{~kJ} / \mathrm{mol}$ for the adsorption of $\mathrm{Ni}$ (II) at $20,30,40$ and $50^{\circ} \mathrm{C}$, respectively.

The negative $\Delta \mathrm{G}^{\circ}$ values indicate that thermodynamically feasible and spontaneous nature of the adsorption of $\mathrm{Ni}$ (II) at 20 and $30^{\circ} \mathrm{C}$. The positive and small values of $\Delta \mathrm{G}^{\circ}$ indicate that the process is feasible but non-spontaneous. The $\Delta \mathrm{H}^{\circ}$ parameter has a value of -33.82 and $-26.48 \mathrm{~kJ} / \mathrm{mol}$ for the adsorption of $\mathrm{Cd}$ (II) and $\mathrm{Ni}$ (II) ions, respectively. These negative values indicate the exothermic nature of the adsorption of both metal ions onto EP in the temperature range of $20-50^{\circ} \mathrm{C}$. The values of $\Delta \mathrm{S}^{\circ}$ are found to be -117.44 and -6.31 $\mathrm{J} / \mathrm{mol} . \mathrm{K}$ for the adsorption of $\mathrm{Cd}$ (II) and $\mathrm{Ni}$ (II), respectively. The negative values of $\Delta \mathrm{S}^{\circ}$ suggest a decrease in the randomness at the solid/solution interface during the adsorption of $\mathrm{Cd}$ (II) and $\mathrm{Ni}$ (II) ions onto EP.

The adsorption capacities $\left(\mathrm{q}_{\mathrm{m}}\right)$ of different adsorbents for adsorption of $\mathrm{Cd}$ (II) and $\mathrm{Ni}$ (II) ions under different environmental conditions reported in the literature are compared in Table 5. It may be seen that $\mathrm{q}_{\mathrm{m}}$ values differ widely for different adsorbents. Comparison of $\mathrm{q}_{\mathrm{m}}$ values shows that EP exhibits a reasonable capacity for $\mathrm{Cd}$ (II) and $\mathrm{Ni}$ (II) adsorption from aqueous solutions. The cost of the adsorbent is also an important issue that must be considered when selecting an adsorbent. The regeneration and reuse of perlite may also play an important role in making this a practical process. The cost of regeneration/disposal of the spent adsorbent would have to be considered in any detailed economic analysis required to determine the most economical adsorbent. 
Table 5: Adsorption capacity of various adsorbents for the adsorption of cadmium and nickel

\begin{tabular}{|c|c|c|c|c|c|}
\hline Cadmium & & & Nickel & & \\
\hline Adsorbent & $q_{m}(m g / g)$ & Reference & Adsorbent & $q_{m}(m g / g)$ & Reference \\
\hline Red mud & 106.064 & Apak et al. (1998) & Seyitomer fly ash & 1.174 & Bayat (2002) \\
\hline Seyitomer fly ash & 0.224 & Bayat (2002) & Pine bark & 6.28 & $\begin{array}{l}\text { Villaescusa et al. } \\
(2000)\end{array}$ \\
\hline Aspergillus niger & 4.0 & Kapoor (1998) & Yohimbe bark & 8.80 & Bayat (2002) \\
\hline Crushed coconut shell & 0.91 & $\begin{array}{l}\text { Bhattacharya and } \\
\text { Venkobachar (1984) }\end{array}$ & Baker's yeast & 11.38 & $\begin{array}{l}\text { Padmavathy et al. } \\
\text { (2003) }\end{array}$ \\
\hline Giridh coal & 0.83 & $\begin{array}{l}\text { Bhattacharya and } \\
\text { Venkobachar (1984) }\end{array}$ & Grape stalks wastes & 10.68 & Villaescusa et al. (2004) \\
\hline $\begin{array}{l}\text { Akaganeite-type } \\
\text { nanocrystals }\end{array}$ & 17.02 & $\begin{array}{l}\text { Deliyanni and Matis } \\
(2005)\end{array}$ & Afsin-Elbistan fly ash & 0.998 & $\begin{array}{l}\text { Al-Asheh and Duvnjak } \\
\text { (1998) }\end{array}$ \\
\hline Rice husk ash & 3.02 & Srivastava et al. (2009) & Rice husk ash & 4.87 & Srivastava et al. (2009) \\
\hline Corncob & 5.04 & $\begin{array}{l}\text { Leyva-Ramos et al. } \\
(2005)\end{array}$ & Bagasse fly ash & 6.51 & Srivastava et al. (2006) \\
\hline Activated carbon & 3.4 & An et al. (2001) & Maple sawdust & 0.294 & Shukla et al. (2005) \\
\hline Olive stone & 7.33 & Calero et al. (2009) & Tea factory waste & 15.26 & $\begin{array}{l}\text { Malkoc and Nuhoglu } \\
(2005)\end{array}$ \\
\hline Expanded perlite & 1.79 & Present work & Expanded perlite & 2.24 & Present work \\
\hline
\end{tabular}

\section{CONCLUSIONS}

The adsorption behavior of Cd (II) and Ni (II) on expanded perlite was investigated in batch experiments. The adsorption was found to be drastically dependent on $\mathrm{pH}$, adsorbent dosage, and contact time. The optimum $\mathrm{pH}$ for adsorption of both metal ions was found to be 6.0. The rate of Cd (II) and $\mathrm{Ni}$ (II) adsorption was rapid. The cadmium-perlite and nickel-perlite systems attained equilibrium in $120 \mathrm{~min}$ and $105 \mathrm{~min}$, respectively. Isotherm analysis of the data showed that the adsorption pattern of both metal ions on EP followed the Freundlich model. Using the Langmuir model equation, the maximum capacity of $\mathrm{EP}$ was found to be $1.79(\mathrm{mg} / \mathrm{g})$ for Cd (II) ions and $2.24(\mathrm{mg} / \mathrm{g}$ ) for Ni (II) ions. The pseudo-second-order reaction rate model described the kinetic data best for both metal ions. Thermodynamic parameters depicted the exothermic nature of adsorption and the process was favorable.

\section{REFERENCES}

Alkan, M. and Dogan, M., Adsorption of copper (II) onto perlite. J. Colloid Interface Sci., 243, 280291 (2001).

Alkan, M. and Dogan, M., in: Encyclopedia of Surface and Colloid Science. Dekker, New York, pp. 3945-3958 (2002).

An, H. K., Park, B. Y. and Kim, D. S., Crab shell for the removal of heavy metals from aqueous solution. Water Res., 35, 3551-3556 (2001).
Apak, R., Guclu, K. and Turgut, M. H., Modeling of copper (II), cadmium (II), and lead (II) adsorption on red mud. J. Colloid and Inter. Sci., 203, 122130 (1998).

Bayat, B., Comparative study of adsorption properties of Turkish fly ash: I. The case of nickel (II), copper (II) and zinc (II). J. Hazard. Mater., 95, 251-273 (2002).

Bayat, B., Comparative study of adsorption properties of Turkish fly ash: II. The case of chromium (VI) and cadmium (II). J. Hazard. Mater., 95, 275-290 (2002).

Benguella, B. and Benaissa, H., Cadmium removal from aqueous solutions by chitin: kinetic and equilibrium studies. Water Res., 36, 2463-2474 (2002).

Bhattacharya, A. K. and Venkobachar, C., Removal of cadmium (II) by low- cost adsorbents. J. Environ. Eng., 110, 110-122 (1984).

Calero, M., Hernainze, F., Blazquez, G., MartinLara, M. A. and Tenorio, G., Biosorption kinetics of $\mathrm{Cd}$ (II), $\mathrm{Cr}$ (III), and $\mathrm{Pb}$ (II) in aqueous solutions by olive stone. Braz. J. Chem. Eng., 26, 265-273 (2009).

Chakir, A., Bessiere, J., Kacemia, K. and Marouf, B., A comparitive study of the removal of trivalent chromium from aqueous solutions by bentonit and expanded perlite. J. Hazard. Mater., B95, 2946 (2002).

Deliyanni, E. A. and Matis, K. A., Sorption of Cd ions onto akaganeite-type nanocrystals. Sep. Purif. Technol., 45, 96-102 (2005).

Do, D. D., Adsorption Analysis: Equilibria and Kinetics. Imperial College Press, London, (1998). 
Dogan, M., Alkan, M., Türlyilmaz, A. and Ozdemir, Y., Kinetics and mechanism of removal of methylene blue by adsorption onto perlite. J. Hazard. Mater., B109, 141-148 (2004).

Gence, H., Tjell, J. C., McConchie, D. and Schuiling, O., Adsorption of arsenic from water using natural red mud. J. Colloid Interf. Sci., 264, 327334 (2003).

Gomez-Salazar, S., Lee, J. S., Heywieller, J. C. and Tavlarides, L. L., Analysis of cadmium adsorption on novel organo-ceramic adsorbents with a thiol functionality. Ind. Eng. Chem. Res., 42, 3403-3412 (2003).

Gupta, V. K., Jain, C. K., Ali, I., Shamra, M. and Saini, V. K., Removal of cadmium and nickel from wastewater using bagasse fly ash-a sugar industry waste. Water Resour., 37, 4038-4044 (2003).

Ho, Y. S. and McKay, G., Pseudo-second-order model for sorption processes. Process Biochem., 34, 451-465 (1999).

Igwe, J. C., Abia, A. A., Ibeh, C. A., Adsorption kinetics and interparticulate diffusivities of $\mathrm{Hg}$, $\mathrm{As}$ and $\mathrm{Pb}$ ions on unmodified and thiolated coconut fiber. Int. J. Environ. Sci. Tech., 5, 83-92 (2008).

Kapoor, A. and Viraraghavan, T., Application of immobilized Aspergillus niger biomass in the removal of heavy metals from an industrial wastewater. J. Environ. Health, 33, 1507-1514 (1998).

Langmuir, I., The adsorption of gases on plane surfaces of glass, mica and platinum. J. Am. Chem. Soc., 40, 1361-1403 (1918).

Lagergren, S., Zur theorie der sogenanntan adsorption gloster stoffe. K. Sven. Vetenskapsakademiens. Handl., 24, 1-39 (1989).

Leyva-Ramos, R., Diaz-Flores, P. E., Aragon-Pina, A., Mendoza-Barron, J. and Guerrero-Coronado, R. M., Adsorption of cadmium (II) from aqueous solution on natural and oxidized corncob. Sep. Purif. Technol., 40, 2079-2094 (2005).

Malkoc, E. and Nuhoglu, Y., Investigation of nickel (II) removal from aqueous solutions using tea factory waste. J. Hazard. Mater., 127, 120-128 (2005).

Marais Barros, A. J., Prasad, S., Duarte Leite, V. and Gouveia Souza, A., The process of biosorption of heavy metals in bioreactors loaded with sanitary sewage sludge. Braz. J. Chem. Eng., 23, 153-162 (2006).
Mathialagan, T. and Viraraghavan, T., Adsorption of cadmium from aqueous solutions by perlite. J. Hazard. Mater., 94, 291-303 (2002).

Nwabanne, J. T. and Ibbokwe, P. K., Kinetics and equilibrium modeling of nickel adsorption by cassava peel. J. Eng. Applied Sci., 3, 829-834 (2008).

Ong, S., Seng, C. and Lim, P., Kinetics of adsorption of $\mathrm{Cu}$ (II) and $\mathrm{Cd}$ (II) from aqueous solution on rice husk and modified rice husk. Electronic J. Environ. Agric. Food Chem., 1764-1774 (2007).

Padmavathy, V., Vasudevan, P. and Dhingra, S. C., Biosorption of nickel(II) ions on Baker's yeast. Process Biochem., 38, 1389-1395 (2003).

Roulia, M. and Vassiliadis, A. A., Sorption characterization of a cationic dye retained by clays and perlite. Micropor. Mesopor. Mater., 116, 732-740 (2008).

Sari, A., Tuzen, M., Citak, D. and Soylak, M., Adsorption characteristics of $\mathrm{Cu}$ (II) and $\mathrm{Pb}$ (II) onto expanded perlite from aqueous solution. J. Hazard. Mater., 148, 387-395 (2007a).

Sari, A., Tuzen, M., and Soylak, M., Adsorption of $\mathrm{Pb}$ (II) and $\mathrm{Cr}$ (III) from aqueous solution on Celtek clay. J. Hazard. Mater., B144, 41-46 (2007b).

Silva, E. A., Cossich, E. S., Tavares' C.G., Cardozo Filho, L., Guirardello, R., Biosorption of binary mixtures of $\mathrm{Cr}$ (III) and $\mathrm{Cu}(\mathrm{II})$ ions by Sargassum sp.. Braz. J. Chem. Eng., 20, 213-227 (2003).

Singh, K. K., Rastogi, R. and Hasan, S. H., Removal of cadmium from waste water using agricultural waste rush polish. J. Hazard. Mater., 121, 51-58 (2005).

Shukla, S. S., Yu, L. J., Dorris, K. L. and Shukla, A., Removal of nickel from aqueous solutions by sawdust. J. Hazard. Mater., 121, 243-246 (2005).

Srivastava, V. C., Mall, I. D., Mishra I. M., Equilibrium modeling of single and binary adsorption of cadmium and nickel onto bagasse fly ash. Chem. Eng. J. 117, 79-91 (2006).

Srivastava, V. C., Mall, I. D. and Mishra I. M., Competitive adsorption of cadmium (II) and nickel (II) from aqueous solution onto rice hush ash. Chem. Eng. Process 48, 370-379 (2009).

Tekin, N., Kadinci, E., Demirbas, O., Alkan, M. and Dogan, M., Surface properties of poly (ninylimidazole)-adsoebed expanded perlite. Micropor. Mesopor. Mater., 93, 125-133 (2006).

Unlü, N. and Ersoz, M., Adsorption characteristics of heavy metal ions onto low cost biopolymeric 
sorbent from aqueous solution. J. Hazard. Mater., 136, No. 2, 272-280 (2006).

Villaescusa, I., Fiola, N., Martinez, M., Miralles, N., Pochc., J. and Serarolsc, J., Removal of copper and nickel ions from aqueous solutions by grape stalks wastes. Water Res. 38, 992-1002 (2004).

Villaescusa, I., Martinez, M. and Miralles, N., Removal of lead (II) and cadmium (II) from aqueous solutions using grape stalk waste. J. Chem Technol. Biotechnol., 75, 1-5 (2000).

Weber, W. J., Physicochemical process for water quality control. Wiley, New York, USA (1972).

Wen, D., Ho, Y. S. and Tang, X., Comparitive sorption kinetic studies of ammonium onto zeolite. J. Hazard. Mater., B133, 252-256 (2006). 